\title{
Social class differences in child mortality, Sweden 1981-1986
}

\author{
Viveca Östberg
}

\begin{abstract}
Study objective-The aim was to analyse social class differences in mortality among Swedish children, 1-19 years old, during the period 1981-86. In order to study the development of these differences, mortality differences during the study period were compared with those 20 years earlier, ie, 1961-66.
\end{abstract}

Design-The study used data from two census linked death registries (CDR80 and CDR60). These were constructed by linkages between the 1980 and 1960 population censuses, respectively, and the corresponding national cause of death registries. Age specific and age standardised death rates, for total and cause specific mortality, were calculated for each social class and for the genders separately. To compare the death rates of social classes, relative risks with approximately $95 \%$ confidence limits were calculated.

Study population-The study included children younger than 16 years at the time of the censuses and all deaths in the age range 1-19 years. The children were followed up for a period of six years after the censuses with respect to mortality.

Main results-During the period 1981-86, children in families of both manual workers and self employed persons had a significantly higher mortality than children in families of non-manual workers.

Conclusions-Although there has been a marked decrease in child mortality during the last decades the study shows that social class differences in child mortality still exist and show little tendency to disappear. f Epidemiol Community Health 1992; 46: 480-484

In an earlier study ${ }^{1}$ we analysed mortality differences among Swedish children (1-19 years old) during the period 1961-1979. It was shown that social class differences existed so that children in families of manual workers and self employed persons had a significantly higher mortality than children of non-manual workers. It has also been suggested that social class differences in mortality among children may, to some extent and for certain diagnoses, persist into adulthood ${ }^{2}$ thereby adding to the importance of the study of these differences.

Since health inequalities are nowadays seen as a major target for health policy, a continuous evaluation of such differences is important. Therefore, this study analyses mortality differences by social class among Swedish children during a more recent period, that is $1981-1986$. This is the main interest here, but the study also includes an attempt to compare the magnitude of mortality differences during the study period with those of an earlier period, ie, 1961-1966.

\section{Methods}

For this study the census linked deaths registry (CDR80) was used. This registry was constructed by a linkage of the 1980 population census and the national cause of death registry for the 1981-1986 period. The linkage was made possible by using the 10 digit personal identification number used in Sweden for both medical and census purposes.

The study population was defined as all those born between 1965 and 1980 who were included in the 1980 population census. Thus the children were younger than 16 years of age at the time of the census. Their mortality was followed up for the period 1981-1986 and all deaths in the age range 1-19 years were included.

In the 1980 census, children living with both parents also received both parents' class position. The measure of social class used here is based on several dimensions. ${ }^{3}$ It divides the working population into employed and self employed. The employed are separated in non-manual and manual groups. Within these groups there is a further division according to level of qualification. The self employed are divided into farmers and other self employed.

The traditional method of assigning class positions to children has been to put them in the same category as the "head of the household" who, if one is present, has been the father. The correctness of this procedure, ie, giving the adult man's position to all family members, has been widely discussed when applied to women who themselves participate in the labour force. This problem also concerns children and arises when classifying children living with two parents who have different class positions, both of which could have an impact on the family situation.

One solution to this problem ${ }^{4}$ is based on the assumption that in the household some positions dominate others, ie, have the greatest influence on such things as ideology, attitudes, behaviour, and consumption patterns of family members. Which of the parents occupies this dominant position is thought to be of no significance.

The basic assumption when developing a ranking order for the dominance of certain positions over others, for members in the same household, is the following: positions of higher qualifications dominate positions of lower, and at the same qualification level non-manual occupations dominate manual. Further, self employed dominate 
employed (except employed professionals) and employed dominate unemployed.

In this study, since information on the position of both parents was available, children in families with only one working parent will receive that person's position, while if there are two parents who occupy different positions the child will be assigned the position that ranks highest on the dominance scale. The information on parental position obtained in this way has been used to divide the children into five social classes. These are referred to as A-E:

$A=$ Professionals, higher managerial and intermediate non-manual

$\mathrm{B}=$ Routine non-manual

$\mathrm{C}=$ Self employed (including farmers)

$\mathrm{D}=$ Skilled workers

$\mathrm{E}=$ Unskilled workers

It is important to notice that these classes are not in themselves considered to be ranked. The proportions of children in each social class were $35.7 \%, 12.5 \%, 12.3 \%, 19.6 \%$, and $19.9 \%$.

Death rates were calculated in order to obtain a comparable mortality measure for the different social classes. The death rate is the number of deaths divided by the number of person-years at risk. The denominators were obtained from a person-years at risk matrix constructed in the following way: the number of persons at risk at the beginning of the study period (ie, in 1980) was estimated from a $4 \%$ random sample of the whole Swedish population. The matrix was constructed by adding a year to each one year age group as a person in the study went through that age. The matrix was also reduced by those dying during the study period. It was reduced by half a year at the year of death and by one year for each of the following years under study. The sums were then aggregated to a person-year matrix, specified for five year age groups, gender, and social class.

The distribution of deaths and person-years at risk by gender and age can be seen in table I. For each social class the death rate was calculated for five year age groups and for the genders separately. From these age specific rates a weighted average was obtained as a measure of the overall death rate for each social class. The weights were proportional to the size of each age group in the

Table I Number of deaths and person-years at risk by gender and age group. Sweden 1981-1986

\begin{tabular}{lccccc}
\hline & \multicolumn{2}{l}{ Number of deaths } & & \multicolumn{2}{c}{ Number of person-years at risk } \\
\cline { 2 - 3 } \cline { 6 - 6 } Age group (years) & Boys & Girls & & Boys & Girls \\
\hline $1-4$ & 137 & 98 & & 436300 & 426592 \\
$5-9$ & 307 & 177 & & 1469563 & 1411920 \\
$10-14$ & 332 & 216 & & 1709722 & 1625744 \\
$15-19$ & 758 & 354 & & 1448564 & 1383845 \\
All ages & 1534 & 845 & & 5064150 & 4848101 \\
\hline
\end{tabular}

Table II Number of deaths and person-years at risk by gender and age group. Sweden 1961-1966

\begin{tabular}{lrrrrr}
\hline & \multicolumn{2}{l}{ Number of deaths } & & \multicolumn{2}{c}{ Number of person-years at risk } \\
\cline { 2 - 3 } \cline { 5 - 6 } Age group (years) & Boys & Girls & & Boys & \multicolumn{1}{c}{ Girls } \\
\hline $1-4$ & 408 & 287 & & 472042 & 447025 \\
$5-9$ & 745 & 480 & & 1491730 & 1409597 \\
$10-14$ & 593 & 402 & & 1640892 & 1556128 \\
$15-19$ & 1080 & 514 & & 1349647 & 1327434 \\
All ages & 2826 & 1683 & & 4954312 & 4740184 \\
\hline
\end{tabular}

whole country at the midpoint of the study period, that is in $1983 .{ }^{5}$ To compare the death rates of social classes, relative risks were calculated with social class A (ie, professionals, higher managerial, and intermediate non-manual) as the reference group. Approximately $95 \%$ confidence intervals were also calculated using a method suggested by Rothman and Boice. ${ }^{6}$

The three most common causes of death among children have been further analysed. They were, referred to by their ICD code (8th revision): Accidents, poisonings and violence (800-999); Cancer (140-239); and Congenital malformations (740-759). The proportions of deaths due to these causes were $51.8 \%, 17.8 \%$, and $8.8 \%$.

In order to compare differences in total mortality in 1981-1986 with those in the earlier period, 1961-1966, another similar registry was used (CDR60). This registry was the result of the linkage of the 1960 population census with the national cause of death registry for the 1961-1979 period. Here the study population was defined as all children born in 1945-1960. All deaths during the period 1961-1966 in the age range 1-19 years were included.

In the 1960 census children were only given the social class of the "head of the household", usually the father, so the registry does not allow one to choose either the father's or the mother's position. The social class measure is also different in the two censuses. Consequently, a comparison has to deal with two major problems, ie, the difference in the methods of assigning social class to children and the difference in social class measures.

The only way the first problem could be dealt with was to alter the way in which social classes were assigned to the children in the 1980 census. Thus in this part of the study the children in the 1965-1980 cohort have been given their fathers' social class. Two smaller problems remain, however. Firstly, children in the 1960 census who were participating in the labour force were excluded, ie, were given their own social class. It was not possible also to exclude those children in the 1980 census, but the proportion of Swedish children working under the age of 16 in 1980 should be negligible. Secondly, in the 1960 census children received their fathers' social class irrespective of whether he was working or not. Therefore children with a long term unemployed father (unemployed for more than four months) had to be excluded, even if the mother was working. In the 1980 census children were assigned their mothers' position in such instances. The proportion of children who should consequently also have been excluded in the 1980 census was small $(2 \cdot 4 \%)$ and their inclusion would therefore make little difference.

The other major problem concerns the measure of social class. The 1980 division into social classes, described earlier, is much more sophisticated than that for 1960. The class measure used in the 1960 census also divides the working population into self employed and employed, and among the latter it distinguishes between nonmanual and manual workers. The most reasonable way of comparing classes in the two periods seems to be to use a rough class classification, even though this does not render the comparison 
identical. Therefore the children will be divided into manual workers (social classes $\mathrm{D}$ and $\mathrm{E}$ in the 1980 census) and "all others". This procedure results in a proportion of children in families of manual workers of $48.4 \%$ in 1960 and $45.5 \%$ in 1980.

Death rates and relative risks for the 1961-1966 period have been calculated as described earlier and the distribution of deaths and person years at risk by gender and age is shown in table II. When calculating relative risks, in this part of the study the group labelled "all others" will serve as the reference group.

\section{Results}

Table III shows the total mortality by social class and age for boys and girls. It can be seen that boys in each social class and within every five year age group have a higher mortality than girls. The overall mortality (ie, age standardised mortality for children 1-19 years old) is higher among children in families of self employed persons and manual workers than among children of nonmanual workers. The excess death rate for children of self employed persons (class $\mathrm{C}$ ) is $58 \%$ for boys and $44 \%$ for girls when compared to the reference group (class A-professionals, higher managerial, and intermediate non-manual). The equivalent figures for children of skilled manual workers (class D) is $31 \%$ for boys and $36 \%$ for girls, and for children of unskilled workers (class E), $58 \%$ for boys and $32 \%$ for girls. Sons of routine non-manual workers (class B) also have an excess death rate of $21 \%$.

The highest mortality is found in the youngest (1-4 years old) and the oldest (15-19 years old) age group. The social class gradient varies, both in

Table III Total mortality (deaths per 100000 person-years at risk) among children and adolescents (1-19 years old), relative risks (RR), and 95\% confidence intervals (CI) by gender, age, and social class. Sweden, 1981-1986

\begin{tabular}{|c|c|c|c|c|c|c|}
\hline \multirow{2}{*}{$\begin{array}{l}\text { Age group } \\
\text { and social } \\
\text { class }^{\mathrm{a}}\end{array}$} & \multicolumn{3}{|l|}{ Boys } & \multicolumn{3}{|l|}{ Girls } \\
\hline & $\begin{array}{l}\text { Death } \\
\text { rate }\end{array}$ & $R R$ & $C I$ & $\begin{array}{l}\text { Death } \\
\text { rate }\end{array}$ & $R R$ & $C I$ \\
\hline $\begin{array}{c}1-4 \text { years } \\
\text { A } \\
\text { B } \\
\text { C } \\
\text { D } \\
\text { E }\end{array}$ & $\begin{array}{l}23 \cdot 8 \\
32 \cdot 8 \\
53 \cdot 6 \\
25 \cdot 1 \\
32 \cdot 5\end{array}$ & $\begin{array}{l}1 \cdot 00^{\mathrm{b}} \\
1 \cdot 38 \\
2 \cdot 25 \\
1 \cdot 06 \\
1 \cdot 37\end{array}$ & $\begin{array}{l}(0.8-2 \cdot 5) \\
(1.3-3.8) \\
(0.6-1.8) \\
(0.8-2.3)\end{array}$ & $\begin{array}{l}20 \cdot 5 \\
22 \cdot 0 \\
33 \cdot 2 \\
17 \cdot 4 \\
24 \cdot 1\end{array}$ & $\begin{array}{l}1.00^{b} \\
1.08 \\
1.62 \\
0.85 \\
1.18\end{array}$ & $\begin{array}{l}(0 \cdot 5-2 \cdot 2) \\
(0 \cdot 8-3 \cdot 1) \\
(0 \cdot 5-1 \cdot 6) \\
(0 \cdot 7-2 \cdot 1)\end{array}$ \\
\hline $\begin{array}{c}\text { 5-9 years } \\
\text { A } \\
\text { B } \\
\text { C } \\
\text { D } \\
\text { E }\end{array}$ & $\begin{array}{l}15.5 \\
14.9 \\
18.6 \\
23.0 \\
29.4\end{array}$ & $\begin{array}{l}1.00 \\
0.96 \\
1.20 \\
1.48 \\
1.89\end{array}$ & $\begin{array}{l}(0 \cdot 6-1 \cdot 5) \\
(0 \cdot 8-1 \cdot 8) \\
(1 \cdot 1-2 \cdot 1) \\
(1 \cdot 4-2 \cdot 6)\end{array}$ & $\begin{array}{r}6 \cdot 6 \\
10 \cdot 1 \\
15 \cdot 1 \\
18 \cdot 7 \\
14 \cdot 3\end{array}$ & $\begin{array}{l}1.00 \\
1.53 \\
2 \cdot 27 \\
2 \cdot 83 \\
2 \cdot 15\end{array}$ & $\begin{array}{l}(0.9-2 \cdot 7) \\
(1.3-3.9) \\
(1.8-4.3) \\
(1.4-3.4)\end{array}$ \\
\hline $\begin{array}{l}\text { 10-14 years } \\
\text { A } \\
\text { B } \\
\text { C } \\
\text { D } \\
\text { E }\end{array}$ & $\begin{array}{l}15 \cdot 1 \\
19 \cdot 8 \\
24 \cdot 0 \\
17 \cdot 4 \\
24 \cdot 5\end{array}$ & $\begin{array}{l}1.00 \\
1.31 \\
1.59 \\
1.15 \\
1.62\end{array}$ & $\begin{array}{l}(0 \cdot 9-1 \cdot 9) \\
(1 \cdot 1-2 \cdot 2) \\
(0 \cdot 8-1 \cdot 6) \\
(1 \cdot 2-2 \cdot 2)\end{array}$ & $\begin{array}{r}11.0 \\
8.9 \\
13.6 \\
15.0 \\
14.7\end{array}$ & $\begin{array}{l}1.00 \\
0.81 \\
1.24 \\
1.36 \\
1.34\end{array}$ & $\begin{array}{l}(0.5-1 \cdot 4) \\
(0 \cdot 8-2 \cdot 0) \\
(0.9-2 \cdot 0) \\
(0.9-2 \cdot 0)\end{array}$ \\
\hline $\begin{array}{c}15-19 \text { years } \\
\text { A } \\
\text { B } \\
\text { C } \\
\text { D } \\
\text { E }\end{array}$ & $\begin{array}{l}39 \cdot 7 \\
47 \cdot 4 \\
57 \cdot 8 \\
55 \cdot 7 \\
61 \cdot 7\end{array}$ & $\begin{array}{l}1.00 \\
1.20 \\
1.46 \\
1.41 \\
1.56\end{array}$ & $\begin{array}{l}(0 \cdot 9-1 \cdot 5) \\
(1 \cdot 2-1 \cdot 8) \\
(1 \cdot 1-1 \cdot 7) \\
(1 \cdot 3-1 \cdot 9)\end{array}$ & $\begin{array}{l}23 \cdot 1 \\
17 \cdot 2 \\
28 \cdot 4 \\
30 \cdot 0 \\
27 \cdot 4\end{array}$ & $\begin{array}{l}1.00 \\
0.75 \\
1.23 \\
1.30 \\
1.19\end{array}$ & $\begin{array}{l}(0.5-1 \cdot 1) \\
(0.9-1 \cdot 7) \\
(1 \cdot 0-1 \cdot 8) \\
(0.9-1 \cdot 6)\end{array}$ \\
\hline $\begin{array}{c}\text { All ages } \\
\text { A } \\
\text { B } \\
\text { C } \\
\text { D } \\
\text { E }\end{array}$ & $\begin{array}{l}24 \cdot 1 \\
29 \cdot 2 \\
38 \cdot 2 \\
31 \cdot 6 \\
38 \cdot 2\end{array}$ & $\begin{array}{l}1.00 \\
1.21 \\
1.58 \\
1.31 \\
1.58\end{array}$ & $\begin{array}{l}(1 \cdot 0-1 \cdot 5) \\
(1 \cdot 3-1 \cdot 9) \\
(1 \cdot 1-1 \cdot 5) \\
(1 \cdot 4-1 \cdot 8)\end{array}$ & $\begin{array}{l}15 \cdot 3 \\
14 \cdot 1 \\
22 \cdot 0 \\
20 \cdot 8 \\
20 \cdot 1\end{array}$ & $\begin{array}{l}1.00 \\
0.92 \\
1.44 \\
1.36 \\
1.32\end{array}$ & $\begin{array}{l}(0 \cdot 7-1 \cdot 2) \\
(1 \cdot 1-1 \cdot 8) \\
(1 \cdot 2-1 \cdot 6) \\
(1 \cdot 1-1 \cdot 6)\end{array}$ \\
\hline
\end{tabular}

shape and size, between the age groups and genders. However, the general pattern is still that children of self employed persons and/or manual workers have the highest mortality.

Figures 1 (boys) and 2 (girls) illustrate age standardised cause specific mortality rates. Among boys, $56 \%$ of all deaths are due to accidents and the excess death rate for sons of self employed persons is $91 \%$, for sons of skilled workers $55 \%$, and for sons of unskilled workers $76 \%$ when compared to the reference group. When one excludes deaths due to accidents, the class differences are diminished but not eradicated and a statistically significant difference of $42 \%$ is still present for sons of unskilled workers. The latter also have a higher mortality from congenital malformations (an excess risk of $63 \%$ ) and cancer (an excess risk of $35 \%$ ). Among girls, deaths from accidents contributed to $44 \%$ of the total mortality. For girls there is also an excess risk of accidents for daughters of self employed persons (of $67 \%$ ) and manual workers (of about $60 \%$ ). After excluding this cause of death an excess risk is still present for daughters in both groups of manual workers $(21 \%$ for skilled and $13 \%$ for unskilled manual workers). Furthermore, there seem to be no social class differences in mortality from cancer among girls, yet for congenital malformations the daughters of self employed persons have an almost threefold elevated death risk.

Table IV shows the total mortality for children in families of manual workers and for children in families of "all others" (ie, not manual workers) by gender and age during the periods 1961-1966 and 1981-1986. There has been a striking decrease in mortality between these periods which has favoured both genders and occurred in every five year age group and in both social classes studied here. If one considers the question of whether the trend is towards a narrowing or a widening of class differences the results presented here are ambiguous. In the youngest age group, 1-4 years old, the class differences might have decreased, at least among boys. On the other hand, a widening of class differences could be emerging among children 5-9 years old. In this age group, sons of manual workers had an excess death rate of $26 \%$ in 1961-1966 which had increased to $64 \%$ in the $1981-1986$ period. Among girls the excess mortality was $6 \%$ during the earlier period and $70 \%$ in the later. In the older age groups the pattern is unclear. Therefore, to summarise, no clear tendency of diminishing class difference could be shown, except possibly among the youngest age group.

\section{Discussion}

There has been a marked decrease in child mortality in Sweden during the last decades. It has also been shown that between 1967 and 1980 the material wellbeing among children increased. ${ }^{7}$ Nevertheless, it seems clear that mortality differences by social class still exist and show little tendency to disappear. During the period 19811986 children, both boys and girls, in families of self employed persons and manual workers had a higher mortality than children in families of non-manual workers. The high death rates among 
children of self employed persons was accounted for chiefly by the children of farmers. Children of farmers constitute $26.8 \%$ of the self employed group. Their relative risk (total mortality 99 deaths) when compared to the reference group was significantly increased to 2.01 (boys) and 1.74 (girls). The equivalent figures for children of self employed persons, other than farmers, were 1.44 (boys) and 1.33 (girls).

One major contributing factor to this pattern was a skew distribution of deaths due to accidents, but this was not the only cause of death relevant for the total mortality differences. Sons of unskilled manual workers also had an excess risk of dying from cancer. The incidence of congenital malformations has been claimed not to be linked to social class in Sweden ${ }^{8}$ but in this study the mortality from this diagnosis varies with social class. Mortality was higher for sons of unskilled manual workers, and this might also be the case for sons of self employed persons. Likewise among girls, daughters of self employed persons had a higher mortality from congenital malformations.

When one looks in particular at the living conditions of farmers, and perhaps also of other self employed groups, the children's environment to a degree reflects the parents' work environment. Among adults, agricultural occupations have appeared to give rise to a large number of serious injuries compared to other occupations, ${ }^{9}$ but whether or not children share some of the hazards is a subject for further study. With regard to congenital malformations these findings are certainly worth consideration. Congenital malformations could be caused by a number of factors related to, for instance, the mother's work or home environment during pregnancy or other aspects of the family situation during that period.

In this study, children living in families where neither of the parents participated in the labour force were excluded. It is important to note that
Figure 1 Mortality (deaths per 100000 person-years at risk) among boys (1-19 years old) by social class and cause of death, Sweden 1981-86.

$R=$ professionals, higher managerial, and intermediate non-manual (reference group) ${ }^{\star} p<0.05 \mathrm{v}$ reference group

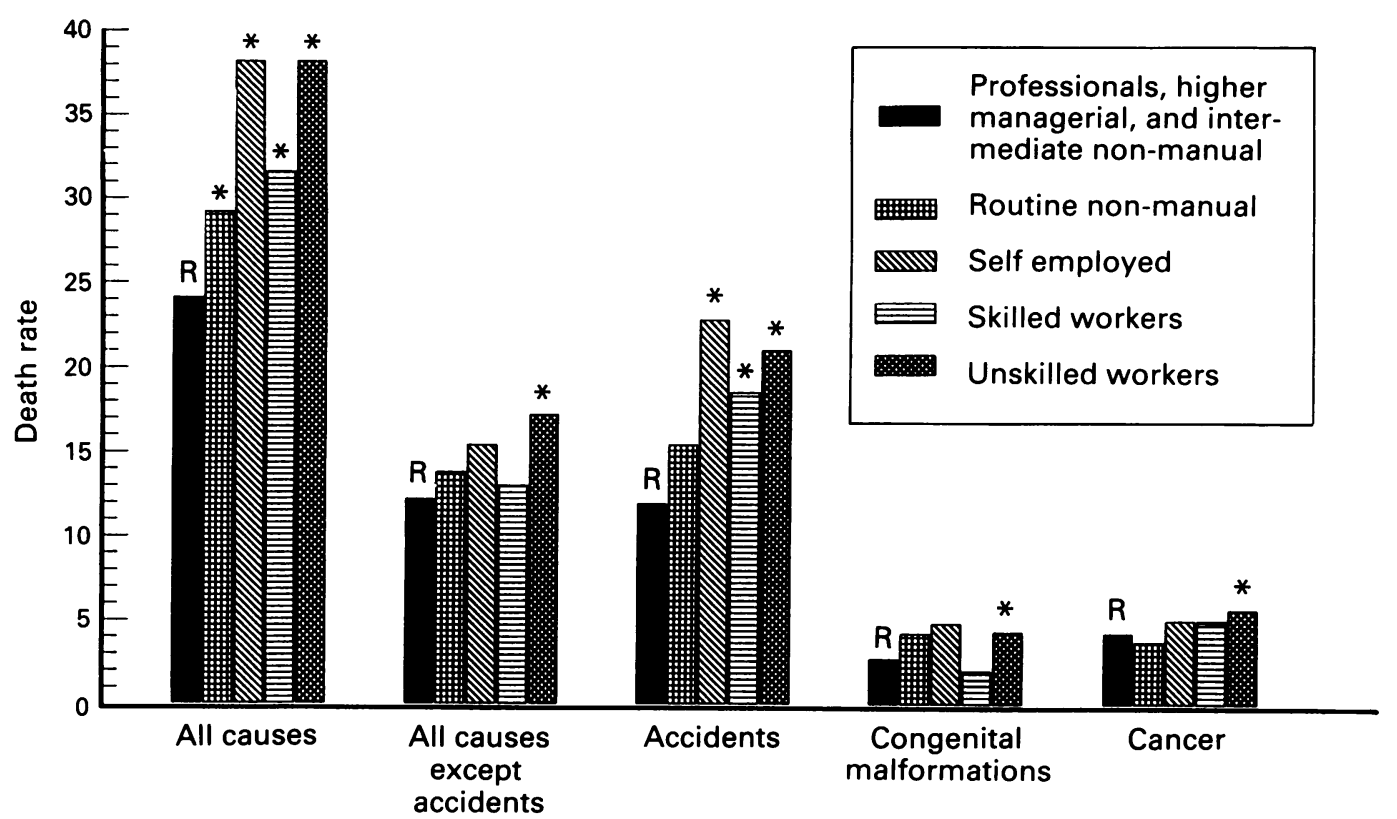

Cause of death

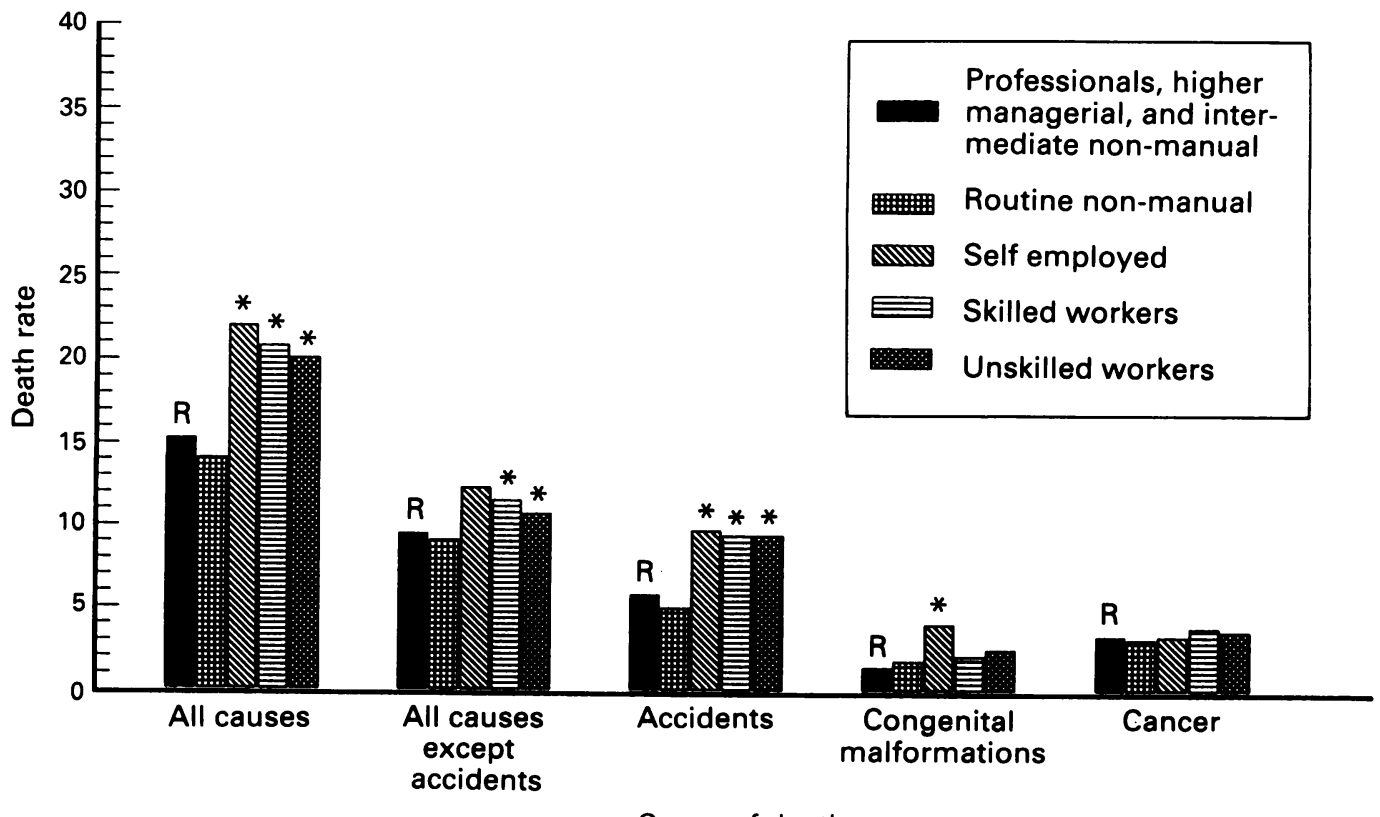

Figure 2 Mortality (deaths per 100000 person-years at risk) among girls (1-19 years old) by social class and cause of death, Sweden 1981-86.

$R=$ professionals, higher managerial, and intermediate non-manual (reference group) ${ }^{\star} p<0.05 \mathrm{v}$ reference group 
class differences exist even when studying only those households where one or both parents have the qualifications and circumstances which enable them to hold an occupation. At the same time it should be pointed out that the excluded group of children had the highest death rates for total mortality (data not presented).

The existence of class differences in mortality and morbidity among children has attracted increasing attention in Sweden. There has also been a tendency to interpret the presence of health inequalities as a failure of social policy. But the magnitude of class differences in Sweden is probably less than in, for instance, Britain ${ }^{10}$ which could indicate that Swedish social policy has had a levelling effect. Perhaps the persistence of health inequalities, in spite of efforts made to erode them, says more about the persistance of such differences.

It seems obvious that reducing mortality in general and reducing mortality differences by social class are two different matters. A reduction of class differences is important both in the interests of equality and because major future improvements of the population's health status could perhaps be achieved by reducing these differences.

Table IV Total mortality during the periods 1961-1966 and 1981-1986 (deaths per 100000 person-years at risk) among children and adolescents (1-19 years old), relative risks $(R R)$, and $95 \%$ confidence intervals (CI) by gender, age, and social class

\begin{tabular}{|c|c|c|c|c|c|c|}
\hline \multirow[b]{2}{*}{$\begin{array}{l}\text { Age group and } \\
\text { social class }\end{array}$} & \multicolumn{3}{|c|}{$1961-1966$} & \multicolumn{3}{|c|}{$1981-1986$} \\
\hline & $\begin{array}{l}\text { Death } \\
\text { rate }\end{array}$ & $R R$ & $C I$ & $\begin{array}{l}\text { Death } \\
\text { rate }\end{array}$ & $R R$ & $C I$ \\
\hline & & & Boys & & & \\
\hline $\begin{array}{l}\text { 1-4 years } \\
\text { All others } \\
\text { Manual workers }\end{array}$ & $\begin{array}{l}75.7 \\
96.7\end{array}$ & $\begin{array}{l}1.00^{\mathrm{a}} \\
1.28\end{array}$ & $(1 \cdot 1-1 \cdot 6)$ & $\begin{array}{l}31 \cdot 2 \\
28 \cdot 3\end{array}$ & $\begin{array}{l}1.00^{\mathrm{a}} \\
0.91\end{array}$ & $(0 \cdot 6-1 \cdot 3)$ \\
\hline $\begin{array}{l}\text { 5-9 years } \\
\text { All others } \\
\text { Manual workers }\end{array}$ & $\begin{array}{l}44 \cdot 3 \\
55 \cdot 6\end{array}$ & $\begin{array}{l}1.00 \\
1.26\end{array}$ & $(1 \cdot 1-1 \cdot 5)$ & $\begin{array}{l}15 \cdot 4 \\
25 \cdot 3\end{array}$ & $\begin{array}{l}1.00 \\
1.64\end{array}$ & $(1 \cdot 3-2 \cdot 1)$ \\
\hline $\begin{array}{l}\text { 10-14 years } \\
\text { All others } \\
\text { Manual workers }\end{array}$ & $\begin{array}{l}32 \cdot 2 \\
40.4\end{array}$ & $\begin{array}{l}1.00 \\
1.26\end{array}$ & $(1 \cdot 1-1 \cdot 5)$ & $\begin{array}{l}18 \cdot 3 \\
20 \cdot 0\end{array}$ & $\begin{array}{l}1 \cdot 00 \\
1 \cdot 10\end{array}$ & $(0.9-1 \cdot 4)$ \\
\hline $\begin{array}{l}\text { 15-19 years } \\
\text { All others } \\
\text { Manual workers }\end{array}$ & $\begin{array}{l}74.9 \\
85.9\end{array}$ & $\begin{array}{l}1.00 \\
1 \cdot 15\end{array}$ & $(1 \cdot 0-1 \cdot 3)$ & $\begin{array}{l}45.8 \\
56.6\end{array}$ & $\begin{array}{l}1.00 \\
1.24\end{array}$ & $(1 \cdot 1-1 \cdot 4)$ \\
\hline $\begin{array}{l}\text { All ages } \\
\text { All others } \\
\text { Manual workers }\end{array}$ & $\begin{array}{l}55.9 \\
68.1\end{array}$ & $\begin{array}{l}1.00 \\
1.22\end{array}$ & $(1 \cdot 1-1 \cdot 3)$ & $\begin{array}{l}28 \cdot 1 \\
33 \cdot 7\end{array}$ & $\begin{array}{l}1.00 \\
1.20\end{array}$ & $(1 \cdot 1-1 \cdot 3)$ \\
\hline & & & Girls & & & \\
\hline $\begin{array}{l}\text { 1-4 years } \\
\text { All others } \\
\text { Manual workers }\end{array}$ & $\begin{array}{l}61 \cdot 1 \\
67 \cdot 1\end{array}$ & $\begin{array}{l}1 \cdot 00 \\
1 \cdot 10\end{array}$ & $(0 \cdot 9-1 \cdot 4)$ & $\begin{array}{l}21 \cdot 2 \\
23 \cdot 1\end{array}$ & $\begin{array}{l}1.00 \\
1.09\end{array}$ & $(0 \cdot 7-1 \cdot 7)$ \\
\hline $\begin{array}{l}\text { 5-9 years } \\
\text { All others } \\
\text { Manual workers }\end{array}$ & $\begin{array}{l}33 \cdot 1 \\
35 \cdot 0\end{array}$ & $\begin{array}{l}1.00 \\
1.06\end{array}$ & $(0 \cdot 9-1 \cdot 3)$ & $\begin{array}{r}9 \cdot 0 \\
15 \cdot 3\end{array}$ & $\begin{array}{l}1.00 \\
1.70\end{array}$ & $(1 \cdot 2-2 \cdot 3)$ \\
\hline $\begin{array}{l}\text { 10-14 years } \\
\text { All others } \\
\text { Manual workers }\end{array}$ & $\begin{array}{l}25.5 \\
26.2\end{array}$ & $\begin{array}{l}1.00 \\
1.03\end{array}$ & $(0 \cdot 8-1 \cdot 2)$ & $\begin{array}{l}11.8 \\
13.6\end{array}$ & $\begin{array}{l}1.00 \\
1.15\end{array}$ & $(0.9-1 \cdot 5)$ \\
\hline $\begin{array}{l}\text { 15-19 years } \\
\text { All others } \\
\text { Manual workers }\end{array}$ & $\begin{array}{l}35.9 \\
41.9\end{array}$ & $\begin{array}{l}1 \cdot 00 \\
1 \cdot 17\end{array}$ & $(1 \cdot 0-1 \cdot 4)$ & $\begin{array}{l}22 \cdot 8 \\
28 \cdot 3\end{array}$ & $\begin{array}{l}1.00 \\
1.24\end{array}$ & $(1 \cdot 0-1 \cdot 5)$ \\
\hline $\begin{array}{l}\text { All ages } \\
\text { All others } \\
\text { Manual workers }\end{array}$ & $\begin{array}{l}37 \cdot 1 \\
40 \cdot 6\end{array}$ & $\begin{array}{l}1.00 \\
1.09\end{array}$ & $(1 \cdot 0-1 \cdot 2)$ & $\begin{array}{l}16 \cdot 1 \\
20 \cdot 1\end{array}$ & $\begin{array}{l}1.00 \\
1.25\end{array}$ & $(1 \cdot 1-1 \cdot 4)$ \\
\hline
\end{tabular}

${ }^{a}$ All others (including all groups that are not manual workers) are the reference group ( $\left.R R=1\right)$
At present, we can only speculate about the origin of these class differences. To be causing mortality and morbidity differences among children the causal factors should be both unevenly distributed and tied to the class structure. Alternatively, an equally distributed causal factor could create such differences if, for instance, the susceptibility differs between social classes, thereby giving rise to synergistic effects. There are still differences in general living conditions between children of non-manual and manual workers in Sweden. Differences in family income, ${ }^{11}{ }^{12}$ housing, ${ }^{12}$ and traffic environment certainly exist, and both day nurseries and schools are characterised by a degree of social segregation. ${ }^{11}$ In addition, the likelihood of growing up in a family where only one parent is working or where one or both parents work irregular hours is greater among manual workers. ${ }^{11} 12$

Further research is needed in order to gain a better understanding of how mortality differences are produced. Although there are systematic social class differences throughout childhood and adolescence these vary both in shape, size, and trend over time between age groups and genders, so it seems plausible that the mechanisms behind these differences could vary. We therefore intend to pursue analyses for separate age groups, in which the age groups are determined by their theorectical and empirical relevance rather than the commonly used five year division.

For discussions of an earlier version of this paper I should like to thank the participants in the Swedish Sociological Association's seminar group for medical sociology at the autumn meeting in 1990 . I should also like to thank Denny Vågerö for valuable comments throughout the work on this paper. The study was supported by the Swedish Social Science Research Council.

1 Vågerö $\mathrm{D}$, Östberg V. Mortality among children and young persons in Sweden in relation to childhood socioeconomic group. $\mathcal{F}$ Epidemiol Community Health 1989; 43: 280-4.

2 Östberg V, Vågerö D. Socio-economic differences in mortality among children. Do they persist into adulthood? Soc Sci Med 1991; 32: 403-10.

3 Andersson L-G, Erikson R, Wärneryd B. Att beskriva den sociala strukturen. Utvärdering av 1974 års förslag till socio-ekonomisk indelning (A memo on the 1974 socioeconomic classification). Statistisk Tidskrift 1981; 2. economic

4 Erikson $R$. Social class of men, women and families. Sociology 1984; 18: 500-14.

5 Statistiska Centralbyrån. Statistisk årsbok 1985 (Statistical abstract of Sweden 1985). Stockholm: Statistics Sweden, abstract

6 Rothman KJ, Boice I. Epidemiological analysis with a programmable calculator. Boston: Epidemiology Research Inc, 1982.

7 Erikson R, Fritzell J. The effects of the social welfare system in Sweden on the well-being of children and the elderly. In: Palmer JL, Smeeding T, Torrey BB, eds. The vulnerable. Washington DC: Urban Institute Press, 1988.

8 Ericson A, Eriksson M, Zetterström R. The incidence of congenital malformations in various socioeconomic groups in Sweden. Acta Paediatr Scand 1984; 73: 664-6.

9 Swedish Commission on Working Conditions. Survey of jobs posing special risks to health. The report of the Health Risks Study Group to the Swedish Commission on Working Study Group to the Swedish Com

10 Vågerö $D$, Lundberg $O$. Health inequalities in Britain and Sweden Lancet 1989; ii: 35-6.

1 Växa i välfärdsland. Socialstyrelsen utvärderar 1990:3 (To arow in welfare courtry Report no 1990:3). Stockholm: grow in welfare country. Report no 1990:3).

2 . childrens living conditions. Living conditions report no childrens living conditions. Living conditic
21). Stockholm: Statistics Sweden, 1981 . 